\title{
Variability and Biogeographical Distribution of Harmful Algal Blooms in Bays of High Productivity off Peruvian Coast (2012-2015)
}

\author{
Sonia Sanchez*, Avy Bernales, Elcira Delgado, Flor del Carmen Chang, Nelly Jacobo and Jorge Quispe
}

Instituto del Mar del Peru (IMARPE), Esquina Gamarra y General Valle s/n Chucuito, La Punta, Callao Casilla Postal 22. Callao, Peru

\begin{abstract}
Harmful Algal Blooms are increasing worldwide problems observed in inshore ecosystems, which support a growing anthropogenic activity that impacts on resources. Results of seasonal and interannual variability of toxic phytoplankton in four bays of the Peruvian sea (Sechura $04^{\circ} \mathrm{S}$, Samanco $09^{\circ} \mathrm{S}$, Miraflores $12^{\circ} \mathrm{S}$ and Paracas $14^{\circ} \mathrm{S}$ ), are shown during spring and summer from 2012 to 2015 . Toxic species such as Pseudo- nitzschia Grupo delicatissima, Grupo P. seriata, Alexandrium peruvianum, Dinophysis caudata, D. acuminata, Gonyaulax spinifera, Azadinium sp, Karlodinium sp., Karenia sp., Protoceratium reticulatum and Prorocentrum minimum were registered, associated with the presence of toxic events, more frequently of okadaic acid (lipophilic toxin - DSP) in Sechura and Samanco for 2012,2013 and 2014 and saxitoxin (Paralytic Toxin - PSP) in Paracas 2012. Sea surface temperature for spring fluctuated between $16.3^{\circ}$ to $19.9^{\circ} \mathrm{C}$ (Sechura-Paracas), and for the summer between $19.3^{\circ}$ to $24.1^{\circ} \mathrm{C}$ (Paracas - Sechura). Physical dynamics were related with seasonal variations, associated to local effects, with slow surface marine currents during austral summer and intense currents during spring, with average values of $<13.91$ and $25.0 \mathrm{~cm} / \mathrm{s}$, respectively, associated with clockwise gyres that influenced the harmful algal blooms. Spearman correlations $(p<0.05)$ between the biological and physicalchemical component were found mainly with temperature $(r=0.665)$, silicates $(r=0.45)$, phosphates $(r=0.48)$ and nitrates $(r=0.50)$.
\end{abstract}

Keywords: HABs; Peruvian Sea; Coastal bays; Harmful algal bloom

\section{Introduction}

Algal blooms or 'red tides' are natural monospecific proliferations of certain species of phytoplankton belonging to different taxonomical groups and some photosynthesizer ciliates that cause changes in the color of the sea turning it reddish, brownish, dark brown or even without color; forming irregular spots or patches that can reach some kilometers [1]. Harmful Algal Blooms are increasing worldwide problems observed in peruvian coastal ecosystem, which supports a growing anthropogenic activity that impacts on resources. For the Northern Humboldt Current Ecosystem (Peruvian Sea), red tides records are available since 1980 with information from coastal laboratories of IMARPE, and a monitoring program was established since 2003. Harmless and harmful (potentially toxic) phytoplankton species have been recorded. Among harmless dinoflagellates, Akashiwo sanguinea, Prorocentrum micans, $P$. gracile, Ceratium fusus v. fusus, C. dens were reported with much frequency. Harmless diatoms such as Pleurosigma sp., Amphiprora sp, Skeletonema costatum, Leptocylindrus danicus, Entomoneis alata v. alata and silicoflagellates such as Dictyocha fibula were reported as well. The first reports of potentially toxic phytoplankton were realized by Pisco-Paracas Coastal Laboratory at IMARPE from 2005-2007, three new species were registered belonging to Prorocentrales, Order: Prorocentrum minimum, $P$. cf. balticum, and $P$. lima considered as potentially toxic Cabello et al. [2], concluded that the intense industrial activity of the fishing factories at the inner part of the bay favored the development of a harmful algal bloom caused by Prorocentrum micans exerting a negative synergic effect on the quality of the water column and sediments, which caused the mortality of the scallops. Here, we assess seasonal and interannual variability of toxic phytoplankton in four bays of the Peruvian sea from 2012 to 2015 looking for relationship between biological and physical-chemical components.

\section{Materials and Methods}

The sampling was carried out during summer and spring from 2012 to 2015 in four bays of the Peruvian sea (Sechura $04^{\circ}$ S, Samanco $09^{\circ} \mathrm{S}$, Miraflores $12^{\circ} \mathrm{S}$ and Paracas $\left.14^{\circ} \mathrm{S}\right)$. Water samples were collected with Niskin bottles at surface and bottom depths for phytoplankton, salinity, nutrients, oxygen, chlorophyll and $\mathrm{pH}$. Temperature was measured with surface thermometer, and water column currents with ADCP. Integrated-depth samples were obtained by using a detachable hose in sections [3]. The quantitative analysis was done by Utermöhl methodology [4], giving the results in cell $\mathrm{L}^{-1}$ (Figures 1 and 2).

\section{Results and Discussion}

The composition of phytoplankton communities reflects life-forms selections modulated by species-specific features [5]. Therefore, species assemblages registered, tend to share characteristics in response to the ecological history of the body of water in which they are found in the different bays studied. Physical dynamics were related with seasonal variations, associated to local effects, with slow surface marine currents during austral summer and intense currents during spring, with average values of $<3.91$ and $25.0 \mathrm{~cm} / \mathrm{s}$, respectively, with clockwise gyres that influenced harmful algal blooms (Figure 3 ).

\section{Statistical analysis}

To explore data dispersion and distribution, boxplots were graphed using MINITAB 16. Spearman's correlation coefficients between potentially toxic phytoplankton abundances (diatoms and dinoflagellates) and physical-chemical parameters were obtained with

*Corresponding author: Sonia Sanchez, Instituto del Mar del Peru (IMARPE) Esquina Gamarra y General Valle s/n Chucuito, La Punta, Callao Casilla Postal 22. Callao, Peru, Tel: +5116250800; E-mail: soniasan@imarpe.gob.pe (or) sosarami@hotmail.com

Received November 21, 2017; Accepted November 25, 2017; Published November 29, 2017

Citation: Sanchez S, Bernales A, Delgado E, Chang FC, Jacobo N, et al. (2017) Variability and Biogeographical Distribution of Harmful Algal Blooms in Bays of High Productivity off Peruvian Coast (2012-2015). J Environ Anal Toxicol 7: 530. doi: 10.4172/2161-0525.1000530

Copyright: () 2017 Sanchez S, et al. This is an open-access article distributed under the terms of the Creative Commons Attribution License, which permits unrestricted use, distribution, and reproduction in any medium, provided the original author and source are credited. 
Citation: Sanchez S, Bernales A, Delgado E, Chang FC, Jacobo N, et al. (2017) Variability and Biogeographical Distribution of Harmful Algal Blooms in Bays of High Productivity off Peruvian Coast (2012-2015). J Environ Anal Toxicol 7: 530. doi: 10.4172/2161-0525.1000530

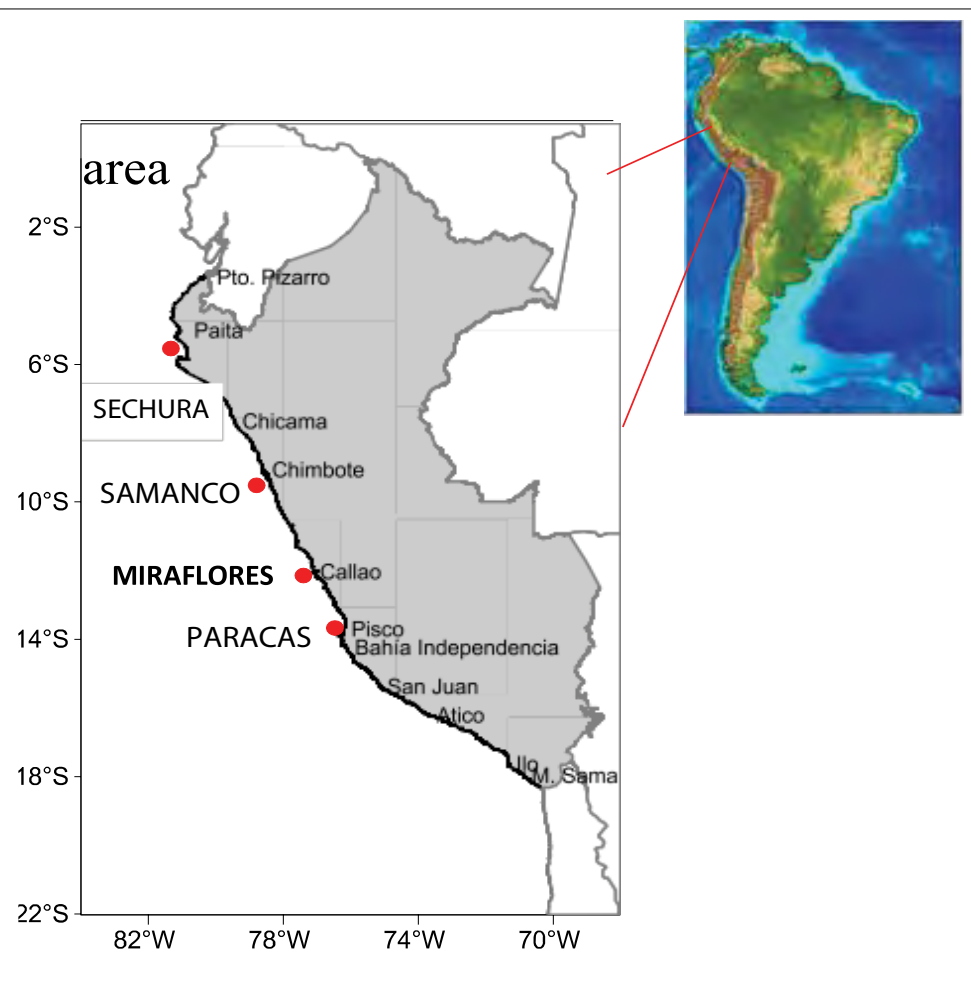

Figure 1: Study area.

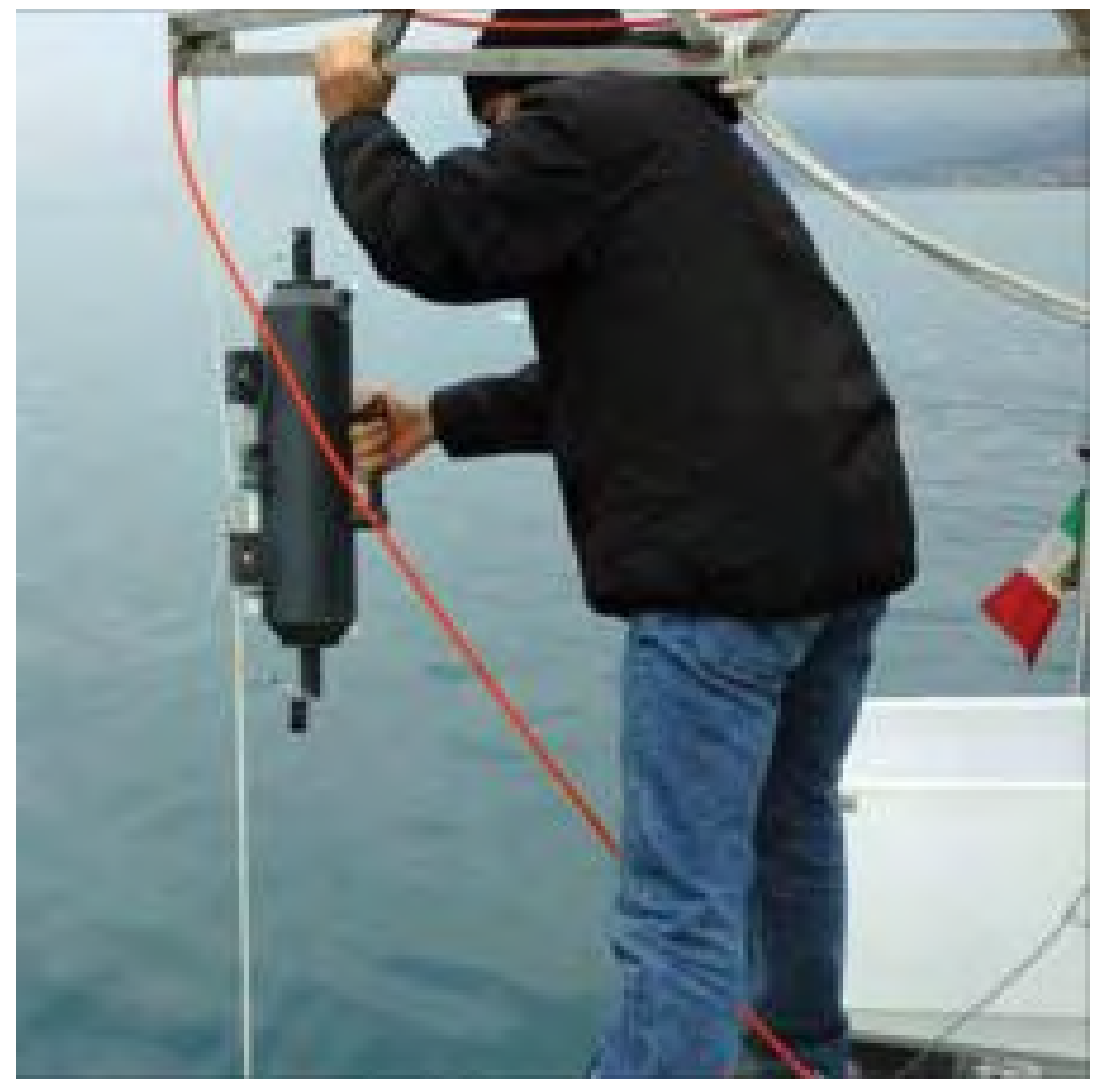

Figure 2: Water sampling by Niskin bottle. 
Citation: Sanchez S, Bernales A, Delgado E, Chang FC, Jacobo N, et al. (2017) Variability and Biogeographical Distribution of Harmful Algal Blooms in Bays of High Productivity off Peruvian Coast (2012-2015). J Environ Anal Toxicol 7: 530. doi: 10.4172/2161-0525.1000530
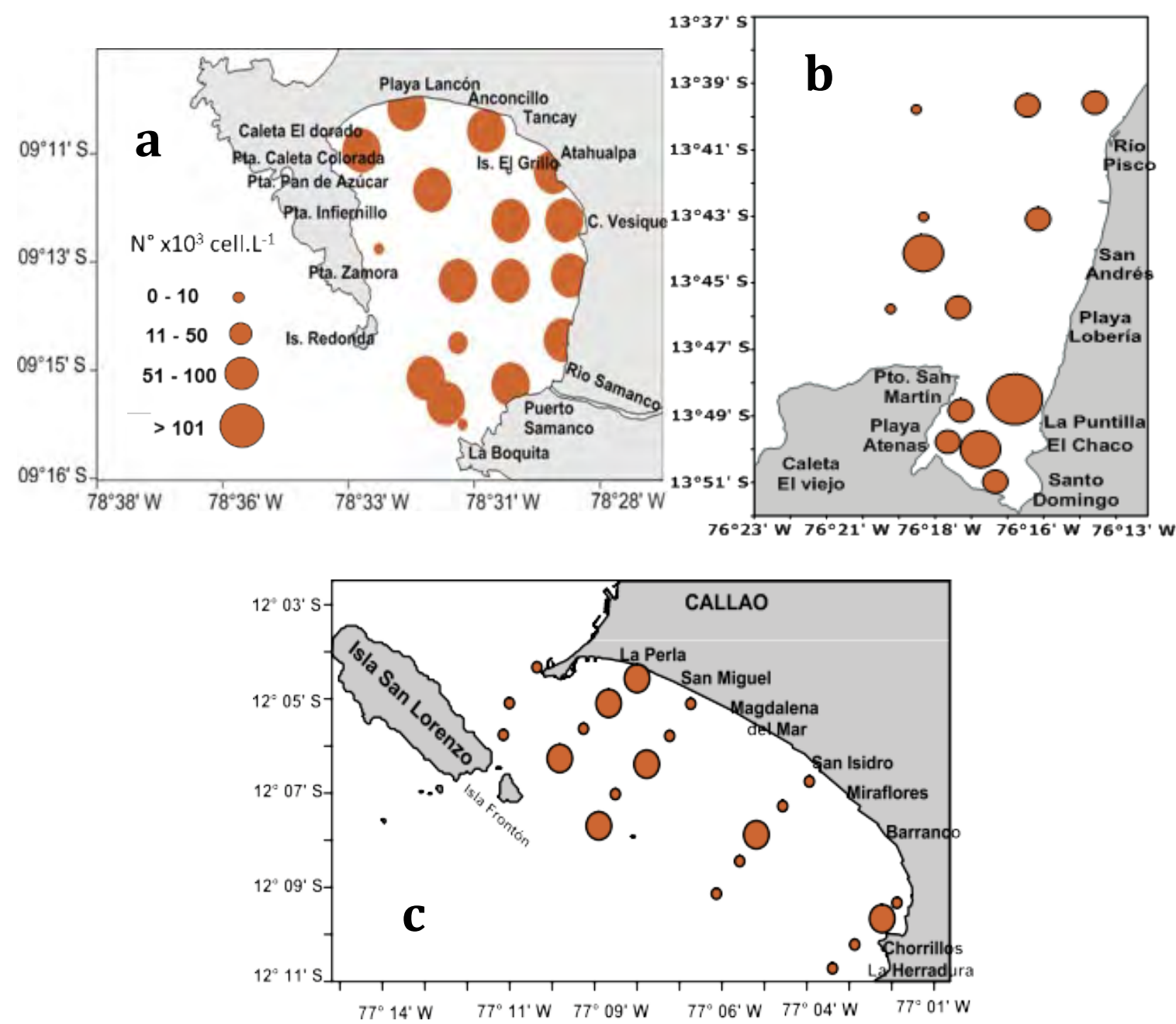

Figure 3: Potentially toxic dinoflagellates abundances in Samanco (a, Spring 2013), Paracas (b, Summer 2013) and Miraflores (c, Summer 2014) bays.

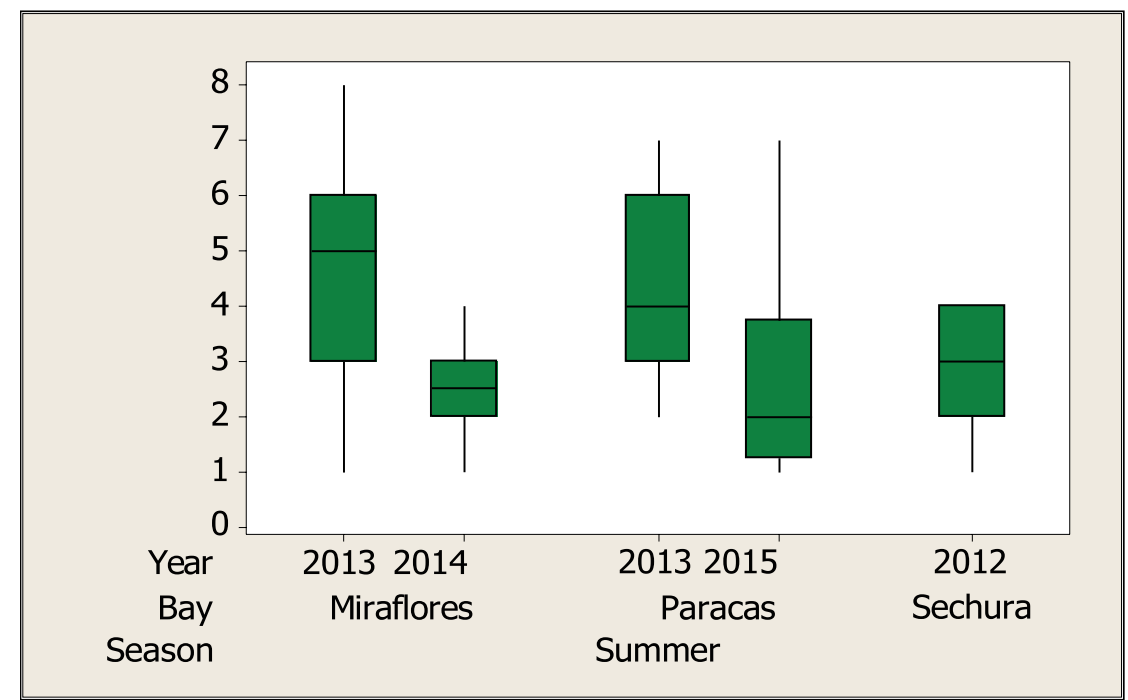

Figure 4: Boxplot diagrams according to bay and study period: Potentially species during austral summer. 
Citation: Sanchez S, Bernales A, Delgado E, Chang FC, Jacobo N, et al. (2017) Variability and Biogeographical Distribution of Harmful Algal Blooms in Bays of High Productivity off Peruvian Coast (2012-2015). J Environ Anal Toxicol 7: 530. doi: 10.4172/2161-0525.1000530

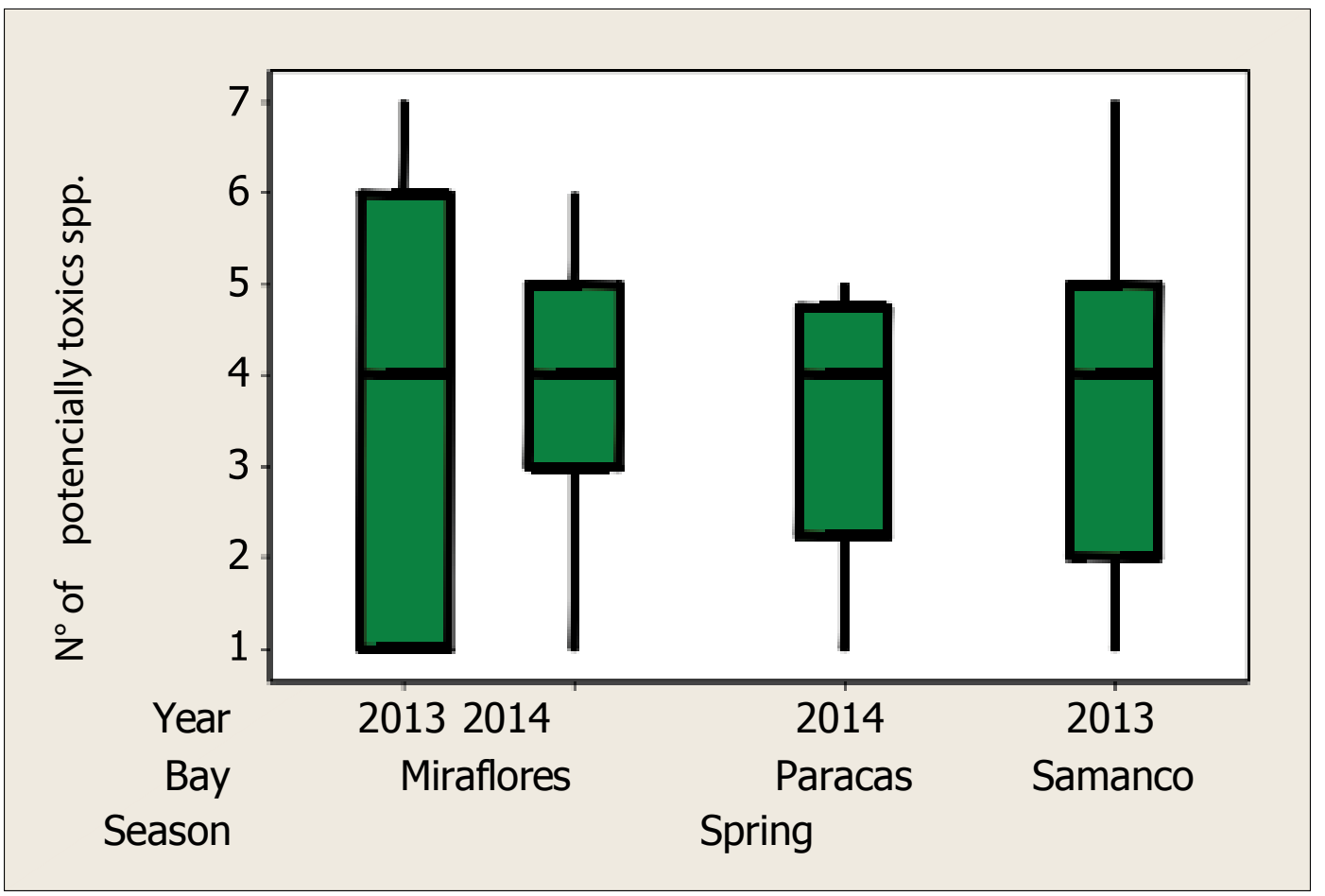

Figure 5: Boxplot diagrams according to bay and study period: Potentially species during spring.

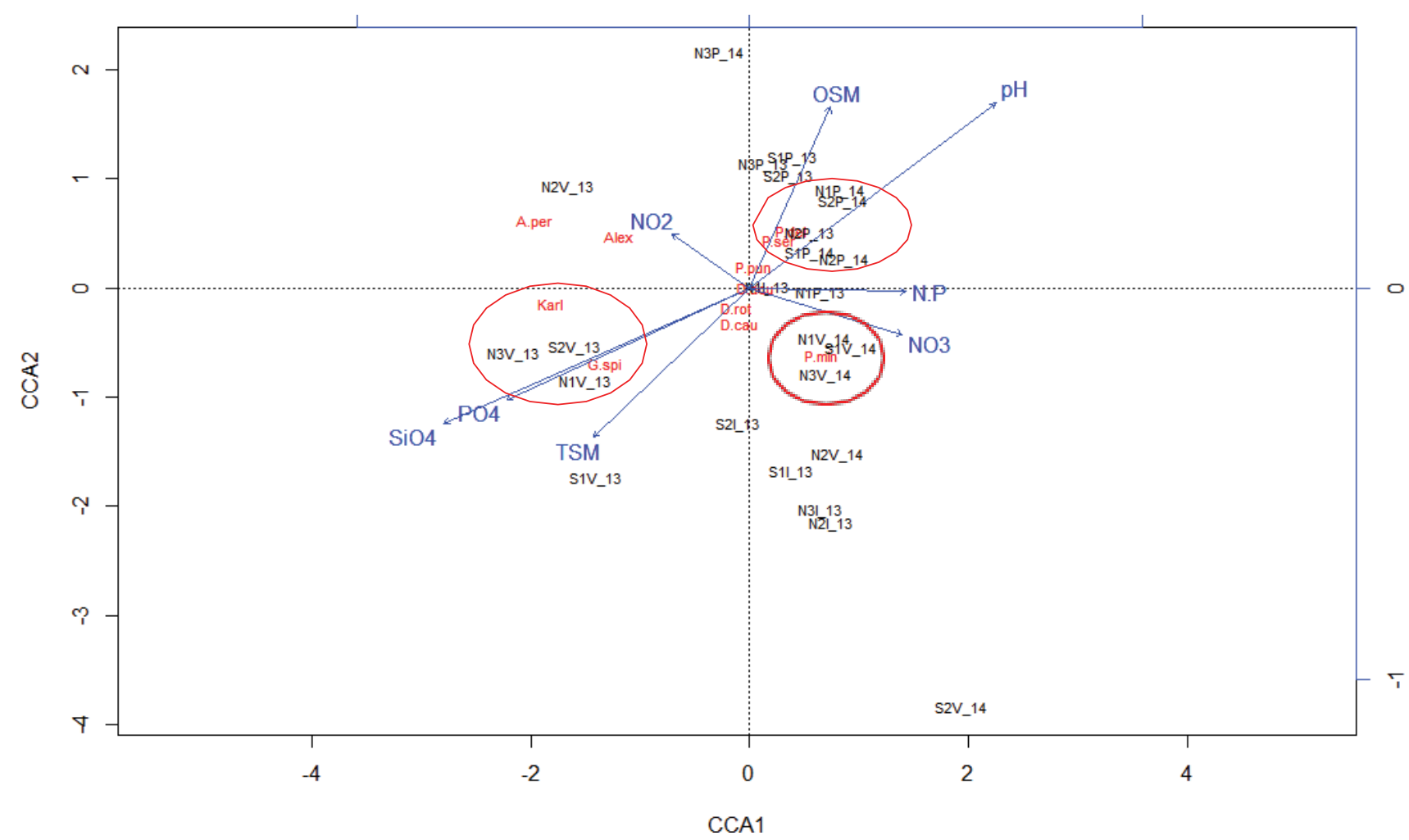

Figure 6: CCA of potentially toxic phytoplankton species cell count and physico-chemical parameters in surface (Miraflores Bay) mainly during summer and spring 2013-2014. 
Citation: Sanchez S, Bernales A, Delgado E, Chang FC, Jacobo N, et al. (2017) Variability and Biogeographical Distribution of Harmful Algal Blooms in Bays of High Productivity off Peruvian Coast (2012-2015). J Environ Anal Toxicol 7: 530. doi: 10.4172/2161-0525.1000530

Page 5 of 5

\begin{tabular}{|c|c|c|c|c|}
\hline \multirow{2}{*}{ Region } & \multirow{2}{*}{ Area } & \multicolumn{2}{|c|}{ Biotoxin } & \multirow{2}{*}{ Year } \\
\hline & & Lipophilic & PSP & \\
\hline \multirow{10}{*}{ Piura $05^{\circ} 12^{\prime} 03^{\prime \prime S}$} & Parachique & 1 & & 2007 \\
\hline & Vichayo & 3 & & $2008-2009$ \\
\hline & Reventazón & 2 & & $2008 ; 2012$ \\
\hline & Barrancos & 5 & & $2010 ; 2012 ; 2013$ \\
\hline & Puerto Rico & 8 & & $2010 ; 2011 ; 2012 ; 2013$ \\
\hline & Chuyillachi & 2 & & $2009 ; 2012 ; 2013$ \\
\hline & Matacaballo & 5 & & $2012 ; 2013$ \\
\hline & San Pedro & 2 & & $2012 ; 2013$ \\
\hline & Delicias & 3 & & $2012 ; 2013$ \\
\hline & Constante & 2 & & $2012 ; 2013$ \\
\hline \multirow{2}{*}{ Ancash $09^{\circ} 32^{\prime} 00^{\prime \prime} \mathrm{S}$} & \multirow{2}{*}{ Samanco } & \multirow{2}{*}{37} & \multirow{2}{*}{2} & 2008; 2009; 2010; 2011; \\
\hline & & & & 2012; 2013; 2014 \\
\hline \multirow{2}{*}{$77^{\circ} 32^{\prime} 00^{\prime \prime} \mathrm{W}$} & Guaynuna & 6 & & $2008 ; 2010 ; 2012 ; 2014$ \\
\hline & Culebras & 2 & & $2008 ; 2014$ \\
\hline Lima $12^{\circ} 02^{\prime \prime} 06^{\prime \prime}$ & Callao & 5 & & 2007; 2010; 2011 \\
\hline \multirow[t]{2}{*}{$\begin{array}{c}\text { Ica } 14^{\circ} 04^{\prime} 00^{\prime \prime S} \\
75^{\circ} 44^{\prime} 00^{\prime \prime}\end{array}$} & Paracas & 5 & 2 & $2010 ; 2011 ; 2012 ; 2013$ \\
\hline & Total & 88 & 4 & \\
\hline
\end{tabular}

Table 1: Toxic events in Peruvian coastal geographic areas 2007-2014.

R program (R studio).

The coastal morphology and topography of each bay, are associated with physical dynamics, eddies (cyclonic or anticyclonic) which induce toxic species retention and the increasing frequency of biotoxin [6]. The toxic species such as Grupo Pseudo-nitzschia delicatissima, Grupo P. seriata, Alexandrium peruvianum, Dinophysis caudata, D. acuminata, Gonyaulax spinifera, Azadinium sp., Karlodinium sp., Karenia sp., Protoceratium reticulatum and Prorocentrum minimum were registered. Through the years, Sechura and Samanco bays were associated with the presence of toxic events, of okadaic acid (lipophilic toxin - DSP) and saxitoxin (Paralytic Toxin - PSP) in Paracas (Table 1).

The highest variability in number of potentially toxic species was recorded off Miraflores and Paracas bays during summer 2013, related to sea surface temperatures between $16.4^{\circ}$ and $24.1^{\circ} \mathrm{C}$; however, potentially toxic dinoflagellates abundances were favored with fewer species in summer 2014. Miraflores and Samanco bays showed high number of potentially toxic species associated with great abundances (cell. $\mathrm{L}^{-1}$ ) during spring (Figures 4 and 5).

A multivariate analysis of ecological data was done for potentially toxic diatoms and dinoflagellates by performing Canonical Correspondence Analysis (CCA) in order to detect patterns or gradients of these species distribution related with environmental parameters. CCA axis 1 and 2 explained $50 \%$ of the variance in the species. Three environmental preferences was found. Species such as Karlodinium sp. (Karl) and Gonyaulax spinifera (G spi) were favoured in low phosphates and silicates waters during summer 2013, while blooms of Group P. delicatissima (P del) and G. P. seriata (P ser) were positively correlated with high oxygen and $\mathrm{pH}$ values during springs 2013 and 2014. Finally, Prorocentrum minimum (P min) occured mainly in high nitrates waters during summer 2014 (Figure 6).

\section{Acknowledgements}

This work has been funded by the Project: Fishing Rights: "Strengthening Prevention System for Early Warning of potentially toxic phytoplankton species in Paita, Chimbote, Callao and Pisco".

\section{References}

1. Sánchez S, Delgado E (1996) Mareas Rojas en el área del Callao $\left(12^{\circ} \mathrm{S}\right) 1980$ 1995. Inf Prog Inst Mar Perú N 44: 19-37.

2. Cabello R, Tam J, Jacinto ME (2002) Procesos naturales y antropogénicos asociados al evento de mortalidad de conchas de abanico ocurrido en la bahía de Paracas (Pisco, Perú) en junio del 2000. Rev Peru Biol 9: 49-65.

3. Lindahl O (1986) A dividable hose for phytoplankton sampling. In Report of the Working Group on phytoplankton and management of their effects. International Council for the Exploration of the Sea 3: 3 .

4. Intergovernmental Oceanographic Comission of UNESCO (2010) Microscopic and molecular methods for quantitative phytoplankton analysis. In: Karlson B, Cusack C, Bresnan E (eds.), Paris, UNESCO (IOC Manuals and Guides, N ${ }^{\circ}$ 55), p: 110.

5. Figueiras FG, Pitcher GC, Estrada M (2006) Harmful Algal Bloom dynamics in relation to physical processes. Ecological Studies 189: 127-138.

6. Trainer VL, Hickey BM, Horner RA (2002) Biological and physical dynamic of domoic acid production off the Washington coast. Limnol Oceanogr 47: 14381446. 